\title{
Do the regular annual extreme water level changes affect the seasonal appearance of Anabaena in Poyang Lake?
}

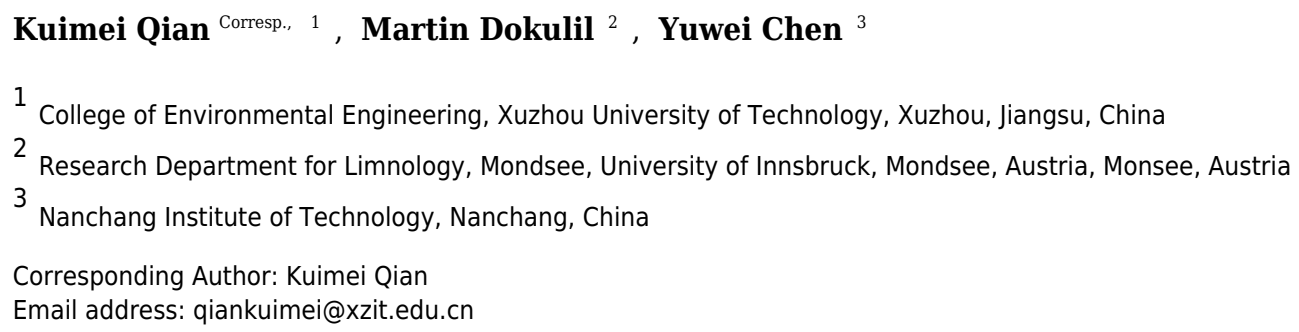

Background. Poyang Lake is an ecosystem experiencing annual variations in water level of up to $14 \mathrm{~m}$. Water level changes were $8.03 \mathrm{~m}$ and $11.22 \mathrm{~m}$ respectively in the years 2013 and 2014. The biomass of Anabaena and heterocyst frequency increased in the summers of recent years. Methods. A weekly to bi-weekly monitoring from June to November 2013 and 2014 was set up to explain the variations of Anabaena appearance in different phases of the water level. Results. Anabaena was present in the lake throughout the year. The average relative biomass of Anabaena in the present study was over $40 \%$, being most abundant in summer. The average heterocyst frequency was $0.23 \%$ in 2013 and $0.76 \%$ in 2014. Correlation analysis indicated a positive trend of Anabaena biomass with water temperature and water level and a negative one with TN, which is the reason for the increase of heterocyst frequency in 2013 and 2014. Heterocyst frequency of Anabaena was positively correlated with water temperature, water level and $\mathrm{PO}_{4}-\mathrm{P}$, and negatively with DIN/DIP, $\mathrm{NO}_{3}-\mathrm{N}$ and TN. Moreover, water temperature and DIN/DIP were significantly correlated with water level, indicating that water level changes have a direct effect on Anabaena and heterocyst formation in Poyang Lake. Conclusions. The results of this study support the hypothesis that increasing biomass and heterocyst formation of Anabaena can be primarily caused by seasonal changes of water level in Poyang Lake. 


\section{Do the regular annual extreme water level changes}

2 affect the seasonal appearance of Anabaena in

3 Poyang Lake?

4 Kuimei Qian ${ }^{1}$, Martin Dokulil ${ }^{2}$, Yuwei Chen ${ }^{3}$

$5 \quad{ }^{1}$ College of Environmental Engineering, Xuzhou University of Technology, Jiangsu Laboratory

6 of Pollution Control and Resources Reuse, Xuzhou, Jiangsu Province, China

$7 \quad 2$ Research Department for Limnology, Mondsee, University of Innsbruck, Mondsee, Austria

$8 \quad{ }^{3}$ Nanchang Institute of Technology, Nanchang, Jiangxi Province, China

10 Corresponding Author:

11 Kuimei Qian ${ }^{1}$

12 Lishui Road, Xuzhou City, Jiangsu Province, 221018, China

13 Email address: qiankuimei@163.com 
16 Do the regular annual extreme water level changes

17 affect the seasonal appearance of Anabaena in

Poyang Lake?

19

20

21

22

23

24

25

26

27

28

29

30

31

32

33

34

35

36

37

38

39

40

41

42

43

44

45

46

47

48

49

50

51

52

53

54

55

Kuimei Qian ${ }^{1}$, Martin Dokulil ${ }^{2}$, Yuwei Chen ${ }^{3}$

${ }^{1}$ College of Environmental Engineering, Xuzhou University of Technology, Jiangsu Laboratory

of Pollution Control and Resources Reuse, Xuzhou, Jiangsu Province, China

${ }^{2}$ Research Department for Limnology, Mondsee, University of Innsbruck, Mondsee, Austria

${ }^{3}$ Nanchang Institute of Technology, Nanchang, Jiangxi Province, China

Corresponding Author:

Kuimei Qian ${ }^{1}$

Lishui Road, Xuzhou City, Jiangsu Province, 221018, China

Email address: qiankuimei@xzit.edu.cn

\section{Abstract}

Background. Poyang Lake is an ecosystem experiencing annual variations in water level of up to $14 \mathrm{~m}$. Water level changes were $8.03 \mathrm{~m}$ and $11.22 \mathrm{~m}$ respectively in the years 2013 and 2014. The biomass of Anabaena and heterocyst frequency increased in the summers of recent years.

Methods. A weekly to bi-weekly monitoring from June to November 2013 and 2014 was set up to explain the variations of Anabaena appearance in different phases of the water level.

Results. Anabaena was present in the lake throughout the year. The average relative biomass of Anabaena in the present study was over $40 \%$, being most abundant in summer. The average heterocyst frequency was $0.23 \%$ in 2013 and $0.76 \%$ in 2014. Correlation analysis indicated a positive trend of Anabaena biomass with water temperature and water level and a negative one with $\mathrm{TN}$, which is the reason for the increase of heterocyst frequency in 2013 and 2014. Heterocyst frequency of Anabaena was positively correlated with water temperature, water level and $\mathrm{PO}_{4}-\mathrm{P}$, and negatively with DIN/DIP, $\mathrm{NO}_{3}-\mathrm{N}$ and TN. Moreover, water temperature and DIN/DIP were significantly correlated with water level, indicating that water level changes have a direct effect on Anabaena and heterocyst formation in Poyang Lake.

Conclusions. The results of this study support the hypothesis that increasing biomass and heterocyst formation of Anabaena can be primarily caused by seasonal changes of water level in Poyang Lake.

\section{Introduction}

As a key variable in hydrology, changes in water level have significant effects on lake ecology and management affecting environmental factors such as turbidity and transparency (Coops, Beklioglu \& Crisman, 2003; Domitrovic, 2003; Lopes, Bicudo \& Ferragut, 2005; 
56 Mihaljević \& Stević, 2011; O’Farrell et al., 2011). Such water level change is usually moderate, 57 multi-annual or annual (Zohary \& Ostrovsky, 2011; Casali et al. 2011; Da Costa, Attayde \& 58 Becker, 2016; Fuentes \& Petrucio, 2015), Poyang Lake experiences a pulse by up to 14 meters once every year (Zhang et al., 2014). The variable water level transport organisms and nutrients throughout the lake in the direction of the water flow from south to north. Environmental changes are largely responsible for temporal patterns in phytoplankton (Huszar et al., 1998) which in turn might be used as an ecological tool to analyze short-term responses (Reynolds, 2002; Rodrigues et al., 2002). Cyanobacterial $\mathrm{N}_{2}$-fixation can be of ecological importance in nitrogen-deficient water (Karl et al., 2002) because fixing atmospheric N provides combined nitrogen to the pelagic ecosystem and hence supports new planktonic production (Capone \& Carpenter, 1982).

Each habitat in the floodplain has different factors that influence the structure and dynamic of aquatic communities. Poyang Lake can be classified as highly eutrophic, due to the excessive inputs from agriculture, industry and waste discharges during intensive economic activities and growing human population in recent decades (Yang et al., 2015). Nutrients in Poyang Lake caused the proliferation of algae (Deng et al., 2011; Zhen et al., 2011, Liu et al., 2016a). Total phytoplankton biomass was high in autumn of the years 2010-2013, associated with cyanobacterial blooms in some regions of the lake in these years (Qian et al., 2016b). Assemblages of Anabaena spp. and Microcystis spp. migrated to the lake surface in some lentic regions and were visible even at the surface in the outlet channel of Poyang Lake. Therefore not only the buoyant Cyanobacteria but also the nutrients flow to this area along with the water current. There is a clear shift of the dominant Cyanobacteria species from Microcystis spp. to Anabaena spp. in the late summer and early autumn. Anabaena, as a nitrogen-fixing species, formed heterocyst in this time.

The aim of the study was to find out which factors affect the seasonal appearance of Anabaena in Poyang Lake. We hypothesize that the transition in water level is responsible for shifts in species domination within the Cyanobacterial assemblage from Microcystis to Anabaena and back. We further hypothesize that increasing biomass and heterocyst formation of Anabaena can be primarily caused by seasonal changes in water level. Such fluctuations alter the physical and chemical parameters of a system, such as Poyang Lake.

66 \\ Materials \& Methods}




\section{Study area}

88 Poyang Lake $\left(28^{\circ} 22^{\prime} \mathrm{N}-29^{\circ} 45^{\prime} \mathrm{N}, 115^{\circ} 47^{\prime} \mathrm{E}-116^{\circ} 45^{\prime} \mathrm{E}\right)$ is located in northern Jiangxi 89 Province. The lake flows from south to north to discharge into the Yangtze River through a 90 narrow outlet at Hukou (Fig. 1). The water level and its annual change are determined by 91 discharges from the five sub-tributaries and the climatic variability in the region. Precipitation 92 increases rapidly from March to August and decreases after September. In response to the annual 93 cycle of precipitation, Poyang Lake has four different phases: low water level phase, increasing 94 water level phase, high water level phase and decreasing water level phase. The water level will 95 increase to higher than $14 \mathrm{~m}$ above sea level (Wu Song datum) at Xingzi in the high water level 96 phase, with the maximum between 16 to $20 \mathrm{~m}$. It disperses into several smaller water bodies in the low water level phase when the water level decreases to $13 \mathrm{~m}$, the point " $\mathrm{S}$ " in Fig. 1. It is divided into two parts by Songmenshan Mountain. The northern part is the water channel joining the Yangtze River, with the length of $40 \mathrm{~km}$ and the width of 3-5 km (the narrowest point is about $2.8 \mathrm{~km}$ ). The area in the northern part between Duchang and Xingzi counties of Poyang Lake was selected for the study (Fig. 1). This area received all the Anabaena from the southern part of the lake. This area forms a narrow meandering channel during low water level phase in winter. Cyanobacteria (mostly Anabaena, Microcystis and Planktothrix) gathered in this area in summer and autumn.

\section{Methods}

Samples were collected weekly or bi-weekly during the periods May to November in 2013 and June to December in 2014. Five stations were selected to sample (Fig. 1). Water transparency was estimated using a $\sim 30 \mathrm{~cm}$ Secchi disc. Water temperature and $\mathrm{pH}$ were measured in situ with multiparameter profiler YSI $6600 \mathrm{~V} 2$. Water depth was measured using a handheld Speedtech Depthmate portable sounder. The water samples were collected by a 'Ruttner'-sampler at three depths (surface, middle and bottom layers of the lake) and mixed in a clean bucket as the final sample at each station. Phytoplankton sub-samples $(1000 \mathrm{~mL})$ were immediately fixed with $10 \mathrm{~mL}$ Lugol's Iodine solution. The phytoplankton taxon was identified and enumerated by the inverted-microscope Nikon TS100-F following the sedimentation and inverted microscope method of Utermöhl (1958). The algal division, taxa, genus, and species were identified according to $\mathrm{Hu}$ and Wei (2006) and the biomass estimated by volume.

117 Heterocyst frequency, the number of heterocyst per unit length of filament (Chan et al., 2004), 
118 were used as an indicator of the $\mathrm{N}_{2}$-fixation capacity of the Cyanobacteria (Laamanen \& Kuosa, 119 2005). Water chemical variables $\left(\mathrm{NO}_{2}-\mathrm{N}, \mathrm{NO}_{3}-\mathrm{N}, \mathrm{NH}_{4}-\mathrm{N}\right.$, and $\left.\mathrm{PO}_{4}-\mathrm{P}\right)$ samples were filtered with $1200.2 \mu \mathrm{m}$ syringe filters before determined. Total $\mathrm{N}$ (TN) and total P (TP) were determined by 121 persulfate oxidation and spectrophotometry (Jin \& Tu, 1990). Total $\mathrm{P}$ was oxidized to $\mathrm{PO}_{4}{ }^{3-}$ at $122120^{\circ} \mathrm{C}$. Dissolved inorganic nitrogen (DIN) is the sum of concentrations of $\mathrm{NO}_{2}-\mathrm{N}_{,} \mathrm{NO}_{3}-\mathrm{N}$ and $123 \mathrm{NH}_{4}-\mathrm{N}$. The chlorophyll a concentration (Chl a) was determined according to Lorenzen (1967). 124 Water level data for the period January 2013 to December 2014 were obtained from the 125 hydrology of the Jiangxi Province website 126 (http://www.jxsl.gov.cn/id_jhsq201404101112508271/column.shtml).

127 All calculations were completed with the statistical package SPSS for Windows (version 128 17.0). One-way analysis of variance tests (ANOVA) was used to determine if the mass 129 concentrations of dissolved nutrients in water $\left(\mathrm{NH}_{4}{ }^{+}-\mathrm{N}, \mathrm{NO}_{3}{ }^{-}-\mathrm{N}\right.$, and $\left.\mathrm{PO}_{4}{ }^{3-}-\mathrm{P}\right)$ differed among 130 the sampling periods. A Spearman rank correlation test was performed to detect correlations 131 between measured physicochemical parameters and the flooding regime to Anabaena heterocyst 132 frequency in Poyang Lake. Graphs were made with SigmaPlot 12.0 (Systat Software Inc.).

\section{Results}

$134 \quad$ Water level changed from $8.67 \mathrm{~m}$ to $16.70 \mathrm{~m}$ in 2013 and from $7.37 \mathrm{~m}$ to $18.59 \mathrm{~m}$ in 2014

135 (Fig. 2 and Table 1). Water temperature ranged from 15 to $33^{\circ} \mathrm{C}$ in 2013 and 12 to $30^{\circ} \mathrm{C}$ in 2014 . 136 The high-water level coincided with the summer temperatures. Water transparency was about $137 \quad 0.5-0.7 \mathrm{~m}$ in May and June at the beginning of the increasing water level phase and it decreased 138 to $0.3-0.4 \mathrm{~m}$ in August of 2013. Water transparency ranged from 0.25 to $0.5 \mathrm{~m}$ in 2014 .

139 The seasonal change in water level triggers variable nutrient concentrations largely due to 140 dilution (Table 1 and Fig. 3). Total nitrogen concentrations varied from 0.49 to $3.07 \mathrm{mg} \mathrm{L}^{-1}$ in 141 the increasing water level phase, averaging $1.70 \mathrm{mg} \mathrm{L}^{-1}$, and ranged from 1.21 to $3.44 \mathrm{mg} \mathrm{L}^{-1}$ in 142 the high-water level phase, averaging $1.85 \mathrm{mg} \mathrm{L}^{-1}$. Nitrate concentrations were between 0.24 and $1431.52 \mathrm{mg} \mathrm{L}^{-1}$ in the increasing water level phase, averaging $0.87 \mathrm{mg} \mathrm{L}^{-1}$, and varied from 0.66 to $1441.63 \mathrm{mg} \mathrm{L}^{-1}$ in the high-water level phase, averaging $0.95 \mathrm{mg} \mathrm{L}^{-1}$. The range of Nitrite 145 concentrations was 0.019 to $0.053 \mathrm{mg} \mathrm{L}^{-1}$ in the increasing water level phase, averaging 0.037 $146 \mathrm{mg} \mathrm{L}^{-1}$, and varied from 0.012 to $0.067 \mathrm{mg} \mathrm{L}^{-1}$ in the high water level phase, averaging $0.037 \mathrm{mg}$ $147 \mathrm{~L}^{-1}$. Ammonium concentrations were between 0.076 to $0.182 \mathrm{mg} \mathrm{L}^{-1}$ in the increasing water level 148 phase, averaging $0.129 \mathrm{mg} \mathrm{L}^{-1}$, and ranged from 0.016 to $0.161 \mathrm{mg} \mathrm{L}^{-1}$ in the high water level 
149 phase, averaging $0.089 \mathrm{mg} \mathrm{L}^{-1}$. Concentrations of $\mathrm{PO}_{4}-\mathrm{P}$ were 0.003 to $0.191 \mathrm{mg} \mathrm{L}^{-1}$ in the 150 increasing water level phase, averaging $0.038 \mathrm{mg} \mathrm{L}^{-1}$, and varied from 0.011 to $0.217 \mathrm{mg} \mathrm{L}^{-1}$ in 151 the high water level phase, averaging $0.045 \mathrm{mg} \mathrm{L}^{-1}$ (Fig. 3). Concentrations from 0.011 to 0.621 $152 \mathrm{mg} \mathrm{L}^{-1}$ characterized total phosphorus (TP) in the increasing water level phase, averaging 0.108 $153 \mathrm{mg} \mathrm{L}^{-1}$, and were 0.038 to $0.252 \mathrm{mg} \mathrm{L}^{-1}$ in the high-water level phase, averaging $0.108 \mathrm{mg} \mathrm{L}^{-1}$. 154 The ration DIN/DIP lies between 4.41 to 506.78 in the increasing water level phase, averaging 155104.02 , and was 4.43 to $88.76 \mathrm{mg} \mathrm{L}^{-1}$ in the high-water level phase, averaging 42.73 (Table 1). 156 There is a considerable difference in nutrient concentrations between the low and high water 157 level for $\mathrm{NH}_{4}-\mathrm{N}, \mathrm{NO}_{2}-\mathrm{N}, \mathrm{PO}_{4}-\mathrm{P}$, as well as for transparency based on one-way ANOVA analysis. 158 Values were significantly different $(\mathrm{p}<0.05)$ among the two water level phases.

159 Significant differences in phytoplankton community composition in different hydrological 160 phases were associated with physicochemical variations leading by water level changes. 161 Cyanobacteria contributed $78.5 \%$ to the average $11.1 \mathrm{mg} \mathrm{L}^{-1}$ of total phytoplankton biomass in 162 the high-water level phase of 2013 (Fig. 4A \& B). The dominant genera were Microcystis, 163 Planktothrix, and Anabaena (Fig. 4C). Among the six species of Anabaena identified, namely 164 Anabaena affinis, A. planctonica, A. smithii, A. circinalis, A. spiroides and A. azotica, the last two were the most prominent ones. The average relative biomass of Anabaena was $43.6 \%$ during 166 the study periods. Higher contributions occurred in May, July and August of 2013 and were over 167 $40 \%$ during most of 2014 .

Anabaena abundance ranged from 5 cells $\mathrm{mL}^{-1}$ to 9500 cells $\mathrm{mL}^{-1}$ (Fig. 5A). It was around 169 50-150 cells $\mathrm{mL}^{-1}$ in most of the time and the high values of $3000-9500$ cells $\mathrm{mL}^{-1}$ were recorded in May and August 2013 and 300-500 cells mL-1 in August and September 2014. The mean filament size was 50 cells, ranging from 25 to 171 cells in 2013, while the mean filament size 172 ranged from 25 cells to 58 cells in 2014 . The average heterocyst frequency was $3.42 \%$ and 173 9.63\% in August of 2013 and 2014, respectively (Fig. 5B). The average heterocyst frequency was $3.65 \%$ in the increasing water level phase, and 3.82\% in the high water level phase for these 175 two years. The greater percentages of heterocysts during high water level are an indirect 176 indication of possible N-fixation, which is supported by the low nitrogen concentration and the 177 low DIN/DIP ratio in Poyang Lake.

178 The interdependence between all variables and the parameters of Anabaena was evaluated 179 by Spearman Rank Correlation (Table 2). The measured physicochemical variables were 
180 significantly correlated with the water level in Poyang Lake. Phytoplankton was positively 181 correlated with water temperature and water transparency, and negatively correlated with SS, 182 turbidity, TN and TP. Anabaena biomass was positively correlated with water temperature and 183 water level, and negatively correlated with TN. Heterocyst frequency of Anabaena was 184 positively correlated with water temperature, water level and $\mathrm{PO}_{4}-\mathrm{P}$, and negatively with 185 DIN/DIP, $\mathrm{NO}_{3}-\mathrm{N}$ and TN.

\section{Discussion}

187 The water level changes of $8.03 \mathrm{~m}$ in 2013 and $11.22 \mathrm{~m}$ in 2014 were by far greater than 188 changes at other sites (Zohary \& Ostrovsky, 2011; Nõges, Nõges \& Laugaste, 2003; Casali et al., 189 2011). Alterations in water level intensely influence nutrient cycling and mixing processes, leading to variations of the aquatic biota and phytoplankton dynamics (Zohary and Ostrovsky, 2011; Bakker \& Hilt, 2016). The significant correlation between water level and the physicochemical variables indicated that the regular annual extreme water level change of Poyang Lake is the key driver for variations of environmental parameters in this floodplain lake ecosystem (Liu, Teubner \& Chen, 2016b).

The high concentrations of TN and TP in Poyang Lake, $1.5 \mathrm{mg} \mathrm{L}^{-1}$ and $0.13 \mathrm{mg} \mathrm{L} \mathrm{L}^{-1}$ respectively, was favorable for the propagation and proliferation of algae in the system (Deng et al. 2011; Zhen et al. 2011). Phytoplankton was positively correlated with water temperature and water transparency, and negatively correlated with SS, turbidity and TN. Phytoplankton usually positively correlated with chemical variables, such as TN and TP. Phytoplankton was negatively correlated with TN and TP in the present study, indicating transporting of the algae from the southern area to the northern area throughout the water flow (Qian et al., 2016a). Cyanobacterial blooms, as the consequence of buoyant migration to the lake surface, were reported by Liu et al. 203 (2016a) and Qian et al. (2016a) from the summer and autumn in 2012 and 2013 in some regions 204 Cyanobacteria were usually subdominant in Lake Poyang (Qian et al., 2016a). Cyanobacteria 205 were usually subdominant but became temporarily the dominant algal group accounting for about 57\% of total phytoplankton biomass replacing diatoms in August 2013 in Lake Poyang (Qian et al., 2016a). The Cyanobacterial biomass was significantly greater in the Eastern Bay 208 (lentic region) than in the lotic region of Northern Poyang Lake (Liu et al., 2016a). The higher nutrient discharge from the southern part of the lake (Liu et al., 2016a; Liu, Qian \& Chen, 2015). 
211 These results indicate transportation of Cyanobacteria with the water flowing from the southern 212 part to the northern part of Poyang Lake because of the buoyant characteristics of Cyanobacteria 213 (Liu et al., 2016a; Liu, Qian \& Chen, 2015).

214 Anabaena biomass was positively correlated with water temperature and water level, and 215 negatively correlated with TN. Similar as in the floodplain lakes of the Paraná basin during the 216 warm season (Emiliani 1990, 1993), high biomass of $\mathrm{N}_{2}$-fixing Anabaena were documented in 217 Poyang Lake. The peak of Anabaena in 2013 was higher than in 2014 because there is a small 218 water level rising in April, which brought the nutrients for the growth of Anabaena and also 219 caused the gathering of Anabaena in this area. In general, warm water temperatures are 220 necessary for the growth of diazotrophic organisms as Stal (2009) pointed out. Consequently, the 221 development of the Anabaena population in Poyang Lake was strongly correlated with water 222 temperature. Highest biomasses occurred and peaked at times when water temperatures were 223 maximal in summer (Qian et al., 2016a) similar to what has been reported elsewhere (Laamanen $224 \&$ Kuosa, 2005). However, Anabaena can be recorded in the water column of Poyang Lake 225 throughout the year. In essence, Anabaena biomass varied synchronously with changes in water 226 temperature.

227 Cyanobacterial $\mathrm{N}_{2}$ fixation is of ecological importance in aquatic environments (Karl et al., 228 2002). When N/P ratios are low, as is often the case in other floodplain lakes, phytoplankton 229 communities become dominated by heterocyst-bearing Cyanobacteria capable of $\mathrm{N}_{2}$ fixation 230 (Lewis \& Wurtsbaugh, 2008). Phytoplankton assemblages were dominated by N-fixing 231 Cyanobacteria when N/P ratios were low in mesocosm experiments (Schindler, 1977; Smith, 232 1983; Levine \& Schindler, 1999; Smith \& Bennett, 1999; Vrede et al., 2009). When the N/P 233 ratio dropped in spring Anabaena rapidly developed and became the dominant biomass 234 component in summer in Chaohu Lake (Deng et al., 2007). Anabaena is one genus of 235 filamentous Cyanobacteria that can exist as plankton, known for its nitrogen-fixing abilities. The 236 formation of heterocysts is induced by the lack of combined nitrogen in the medium (Schindler, 237 1977) and the number of heterocysts correlates with the $\mathrm{N}_{2}$ fixation activity of the population 238 (Lindahl, Wallström \& Brattberg, 1980; Riddolls, 1985). When DIN concentration is at limiting 239 levels, the ability to fix $\mathrm{N}_{2}$ is an advantage for Cyanobacteria bearing heterocysts (Smith, 1983; 240 Hense \& Beckmann, 2006; Piehler et al., 2009). In the present study, heterocyst frequency of 241 Anabaena was positively correlated with water temperature, water level and $\mathrm{PO}_{4}-\mathrm{P}$, and 
242 negatively with DIN/DIP, $\mathrm{NO}_{3}-\mathrm{N}$ and $\mathrm{TN}$, which is the reason for the increase of heterocyst 243 frequency at high water level in both years. Therefore, Anabaena was able to propagate with low 244 nitrogen concentration.

245 In addition, Anabaena is buoyant, enabling it to float to the surface to make the most of the 246 available light and atmospheric nitrogen (Walsby et al., 1989). This is the reason that visible 247 floating migration to the lake surface of Cyanobacteria blooms occurred during summer and 248 autumn in 2013 -2014 in some regions of Poyang Lake when Anabaena was the dominant 249 species (Qian et al., 2016b). Anabaena can fix atmospheric nitrogen at such low levels of 250 nitrogen in Poyang Lake during the high water level phase that their growth is not limited. 251 Anabaena biomass was positively correlated with water temperature and water level, and 252 negatively correlated with $\mathrm{TN}$, which is the reason for the increase of heterocyst frequency in the 253 present study.

254 Water level fluctuations have an overall impact on phytoplankton community composition, 255 through affecting the physical and chemical variables in Poyang Lake (Qian et al., 2016a), which 256 can be verified by the significant correlation between water level and the measured 257 environmental variables. Low and high water level periods differed in several water 258 physicochemical characteristics in Poyang Lake, such as $\mathrm{NO}_{2}^{-}-\mathrm{N}, \mathrm{NO}_{3}^{-}-\mathrm{N}, \mathrm{TN}$ and TP. The water 259 level change coincided with the season in Poyang Lake. The summer population of Anabaena 260 usually contains heterocysts, while filaments were usually devoid of heterocysts in winter and 261 early spring (Laamanen, 1996). The average contribution of Anabaena to Cyanobacterial 262 biomass was $43.55 \%$ and heterocyst frequency was higher than 3\% in high-water level phases in 263 Poyang Lake. We conclude that variations in environmental parameters related to both seasonal 264 variations and water level changes triggered the variations in Anabaena biomass and heterocyst 265 frequency.

\section{Conclusions}

267 Cyanobacteria biomass accounted for about $57 \%$ of total phytoplankton biomass, 268 temporarily becoming the dominant species even replacing diatoms in August in 2013. The 269 dominant species of Cyanobacteria were nitrogen-fixing Anabaena, which was present 270 throughout the year. The average relative biomass of Anabaena during the study period was over $27140 \%$, being most abundant in summer. When water level increased, Anabaena became the 272 dominant species, produced a high number of heterocysts, reflecting relatively nitrogen 
273 deficiency in Lake Poyang during this period. The results of the study support the hypothesis that 274 increasing biomass and heterocyst formation of Anabaena were primarily triggered by variations 275 in the physicochemical factors, such as high water temperature and suitable nutrients in summer 276 and autumn, driven by the regular annual extreme water level change of Poyang Lake.

\section{Acknowledgments}

278 We want to thank all colleges who collected and processed samples for the monitoring 279 program from the Poyang Lake Laboratory for Wetland Ecosystem Research.

\section{References}

281

282

283

284

285

286

287

288

289

290

291

292

293

294

295

296

297

298

299

300

301

302

303

304

305

Bakker ES, Hilt S. 2016. Impact of water-level fluctuations on Cyanobacterial blooms: options for management. Aquatic Ecology 50(3):485-498.

Capone DG, Carpenter EJ. 1982. Nitrogen Fixation in the Marine Environment. Science 217(4565): 1 140-1 142 .

Casali S, Calijuri C, Barbarisi MD, Renó VF, Affonso AG, Barbosa C, Silva TS, Novo EM. 2011. Impact of the 2009 extreme water level variation on phytoplankton community structure in Lower Amazon floodplain lakes. Acta Limnologica Brasiliensia, 23(3):260-270.

Chan F, Pace M, Howarth R, Marino R. 2004. Bloom formation in heterocystic nitrogen-fixing Cyanobacteria: The dependence on colony size and zooplankton grazing. Limnology and Oceanography 49(6): 2 171-2 178.

Coops H, Beklioglu M, Crisman TL. 2003. The role of water-level fluctuations in shallow lake ecosystems - workshop conclusions. Hydrobiologia 506: 23-27.

Da Costa MRA, Attayde JL, Becker V. 2016. Effects of water level reduction on the dynamics of phytoplankton functional groups in tropical semi-arid shallow lakes. Hydrobiologia 29(1):1-15.

Deng D, Xie P, Zhou Q, Yang H, Guo L. 2007. Studies on temporal and spatial variations of phytoplankton in Lake Chaohu. Journal of Integrative Plant Biology 49 (4): 409-418.

Deng X, Zhao Y, Wu F, Lin Y, Lu Q, Dai J. 2011. Analysis of the trade-off between economic growth and the reduction of nitrogen and phosphorus emissions in the Poyang Lake Watershed, China. Ecological Modelling 222(2): 330-336.

Domitrovic, Y.Z., 2003. Effect of fluctuations in water level on phytoplankton development in three lakes of the Paraná River floodplain (Argentina). Hydrobiologia 510: 175-193.

Emiliani MOG. 1990. Phytoplankton ecology of the Middle Paraná River. Acta Limnologica Brasiliensia 3: 391-417.

Emiliani MOG. 1993. Seasonal succession of phytoplankton in a lake of the Paraná River floodplain, Argentina. Hydrobiologia 264: 101-114. 
306 Fuentes EV, Petrucio MM. 2015. Water level decrease and increased water stability promote

307

308

309

310

311

312

313

314

315

316

317

318

319

320

321

322

323

324

325

326

327

328

329

330

331

332

333

334

335

336

337

338 phytoplankton growth in a mesotrophic subtropical lake. Marine and Freshwater Research 66(8):711.

Hense I, Beckmann A. 2006. Toward a model of Cyanobacteria life cycle —effects of growing and resting stages on bloom formation of $\mathrm{N}_{2}$-fixing species. Ecological Modelling 195: 205-218.

Hu H, Wei Y. 2006. The Freshwater Algae of China Systematics, Taxonomy and Ecology. Beijing: Chinese Science Press.

Huszar VLM, Silva LHS, Domingos P, Marinho M, Melo S. 1998. The relationship between phytoplankton composition and physical-chemical variables: a comparison of taxonomic and morphological-functional descriptors in six temperate lakes. Hydrobiologia 369-370(0): 59-71.

Jin $\mathrm{X}, \mathrm{Tu}$ Q. 1990. Lake eutrophication survey specification (second edition).Beijing: Chinese Environmental Science Press.

Karl D, Michaels A, Bergman B, Capone D, Carpenter E, Letelier R, Lipschultz F, Paerl H, Sigman D Stal L. 2002. Dinitrogen fixation in the world's oceans. Biogeochemistry 57/58: 47-98.

Laamanen M, Kuosa H. 2005. Annual variability of biomass and heterocysts of the $\mathrm{N}_{2}$-fixing cyanobacterium Aphanizomenon flos-aquae in the Baltic Sea with reference to Anabaena spp. and Nodularia spumigena. Boreal Environment Research 10(1): 19-30.

Laamanen M. 1996. Cyanoprokaryotes in the Baltic Sea ice and winter plankton. Algological Studies 83: 423-433.

Levine SN, Schindle DW. 1999. Influence of nitrogen to phosphorus supply ratios and physicochemical conditions on Cyanobacteria and phytoplankton species composition in the Experimental Lakes Area, Canada. Canadian Journal of Fisheries and Aquatic Sciences 56: 451-466.

Lewis WM, Wurtsbaugh WA. 2008. Control of lacustrine phytoplankton by nutrients: erosion of the phosphorus paradigm. International Review of Hydrobiology 93(4-5): 446-465.

Lindahl G, Wallström K, Brattberg G. 1980. Short-term variations in nitrogen fixation in a coastal area of the Northern Baltic. Archiv fur hydrobiologie 89: 88-100.

Liu X, Li Y, Liu B, Qian K, Chen Y, Gao J. 2016a. Cyanobacteria in the complex river-connected Poyang Lake: horizontal distribution and transport. Hydrobiologia 768 (1): 95-110.

Liu X, Qian K, Chen Y. 2015. Effects of water level fluctuations on phytoplankton in a Changjiang River floodplain lake (Poyang Lake): Implications for dam operations. Journal of Great Lakes Research 41(3):770-779.

Liu X, Teubner K, Chen Y. 2016b. Water quality characteristics of Poyang Lake, China, in response to changes in the water level. Hydrology Research 47(S1): 238-248. 
339

340

341

342

343

344

345

346

347

348

349

350

351

352

353

354

355

356

357

358

359

360

361

362

363

364

365

366

367

368

369

370

371

372

Lopes MRM, Bicudo CEM, Ferragut M C. 2005. Short term spatial and temporal variation of phytoplankton in a shallow tropical oligotrophic reservoir, southeast Brazil. Hydrobiologia 542: 235247.

Lorenzen CJ. 1967. Determination of chlorophyll and pheo-pigments: spectrophotometric equations.

Mihaljević M, Stević F. 2011. Cyanobacterial blooms in a temperate river-floodplain ecosystem: the importance of hydrological extremes. Aquatic Ecology 45: 335-349.

Nõges T, Nõges P, Laugaste R. 2003. Water level as the mediator between climate change and phytoplankton composition in a large shallow temperate lake. Hydrobiologia 506-509(1): 257-263.

O’Farrell I, Izaguirre I, Chaparro G, Unrein F, Sinistro R, Pizarro H, Rodríguez P, Pinto P T, Lombardo R, Tell G. 2011. Water level as the main driver of the alternation between a free-floating plant and a phytoplankton dominated state: a long-term study in a floodplain lake. Aquatic Sciences 73:275-287.

Padisák J, Barbosa F, Koschel R, Krienitz L.2003. Deep layer cyanoprokaryota maxima in temperate and tropical lakes. Archiv Fur Hydrobiologie 58: 175-199.

Piehler MF, Dyble J, Moisander PH, Chapman AD, Hendrickson J, Paerl HW. 2009. Interactions between nitrogen dynamics and the phytoplankton community in Lake George, Florida, USA. Lake and Reservoir Management 25: 1-14.

Qian K, Liu X, Chen Y. 2016a. Effects of extreme water level changes on phytoplankton succession in Poyang Lake, China - a five year study. Ecohydrology \& Hydrobiology 16(3): 175-184.

Qian K, Liu X, Duan M, Chen Y. 2016b. Distribution and its influencing factors of bloom-forming Cyanobacteria in Poyang Lake. China Environmental Science 36(1): 261-267 (in Chinese with English abstract).

Reynolds CS. 2002. Ecological pattern and ecosystem theory. Ecological Modelling 158(3): 181-200.

Riddolls A. 1985. Aspects of nitrogen fixation in Lough Neagh I Acetylene reduction and the frequency of Aphanizomenon flos-aquae heterocysts. Freshwater Biology 15(3): 289-297.

Rodrigues LC, Train S, Roberto M, Pagioro TA.2002. Seasonal fluctuation of some limnological variables on a floodplain lake (Patos lagoon) of the Upper Paraná River, Mato Grosso do Sul State, Brazil. Brazilian Archives of Biology and Technology 45(4): 499-513.

Schindler DW. 1977. Evolution of phosphorus limitation in lakes. Science 195: 260-262.

Smith VH, Bennett SJ. 1999. Nitrogen: phosphorus supply ratios and phytoplankton community structure in lakes. Archiv für Hydrobiologie 146: 37-53.

Smith VH. 1983. Low nitrogen to phosphorus ratios favor dominance by blue-green algae in lake phytoplankton. Science 221: 669-671.

Stal LJ. 2009. Is the distribution of nitrogen-fixing Cyanobacteria in the oceans related to temperature? Environmental Microbiology 11(7): 1632-1645. 
373 Utermöhl M. 1958. Zur Vervollkomnung der quantitativen Phytoplankton Methodik. Internationale $374 \quad$ Vereiningung fuer Theoretische und Angewandte Limnologie 9: 1-38.

375 Vrede T, Ballantyne A, Mille-Lindblom C, Algesten G, Gudasz C, Lindahl S, Brunberg A K. 2009. 376 Effects of $\mathrm{N} / \mathrm{P}$ loading ratios on phytoplankton community composition, primary production and $\mathrm{N}$ 377 fixation in a eutrophic lake. Freshwater Biology 54: 331-344.

378 Walsby AE, Reynolds CS, Oliver RL, Kromkamp J. 1989. The role of gas vacuoles and carbohydrate 379 content in the buoyancy and vertical distribution of anabaena minutissima in Lake Rotongaio, New 380 Zealand. Expert Review of Clinical Immunology 11(sup1): 25-31.

381 Yang Z, Wang L, Liang T, Huang M. 2015. Nitrogen distribution and ammonia release from the 382 overlying water and sediments of Poyang Lake, China. Environmental Earth Sciences 74: 771-778.

383 Zhang Q, Ye X, Werner A, Li Y, Yao J, Li X, Xu C. 2014. An investigation of enhanced recessions in 384 Poyang Lake: Comparison of Yangtze River and local catchment impacts. Journal of Hydrology $385 \quad 517(2): 425-434$.

386 Zhen L, Li F, Huang H Q, Dilly O, Wei Y, Yang L, Cao X. 2011. Households' willingness to reduce 387 pollution threats in the Poyang Lake region, southern China. Journal of Geochemical Exploration $388 \quad$ 110(1): $15-22$.

389 Zohary T, Ostrovsky I. 2011. Ecological impacts of excessive water level fluctuations in stratified 390 freshwater lakes. Inland Waters 1: 47-59. 
Figure 1

Map of Poyang Lake indicating Songmen Mountain and the reference point ' $S$ ' (refer to the text).

The insert shows the area at $13 \mathrm{~m}$ water level in dark grey and at $20 \mathrm{~m}$ water level in light grey. The locations of the sampling stations are indicated by numbers \#1-5.

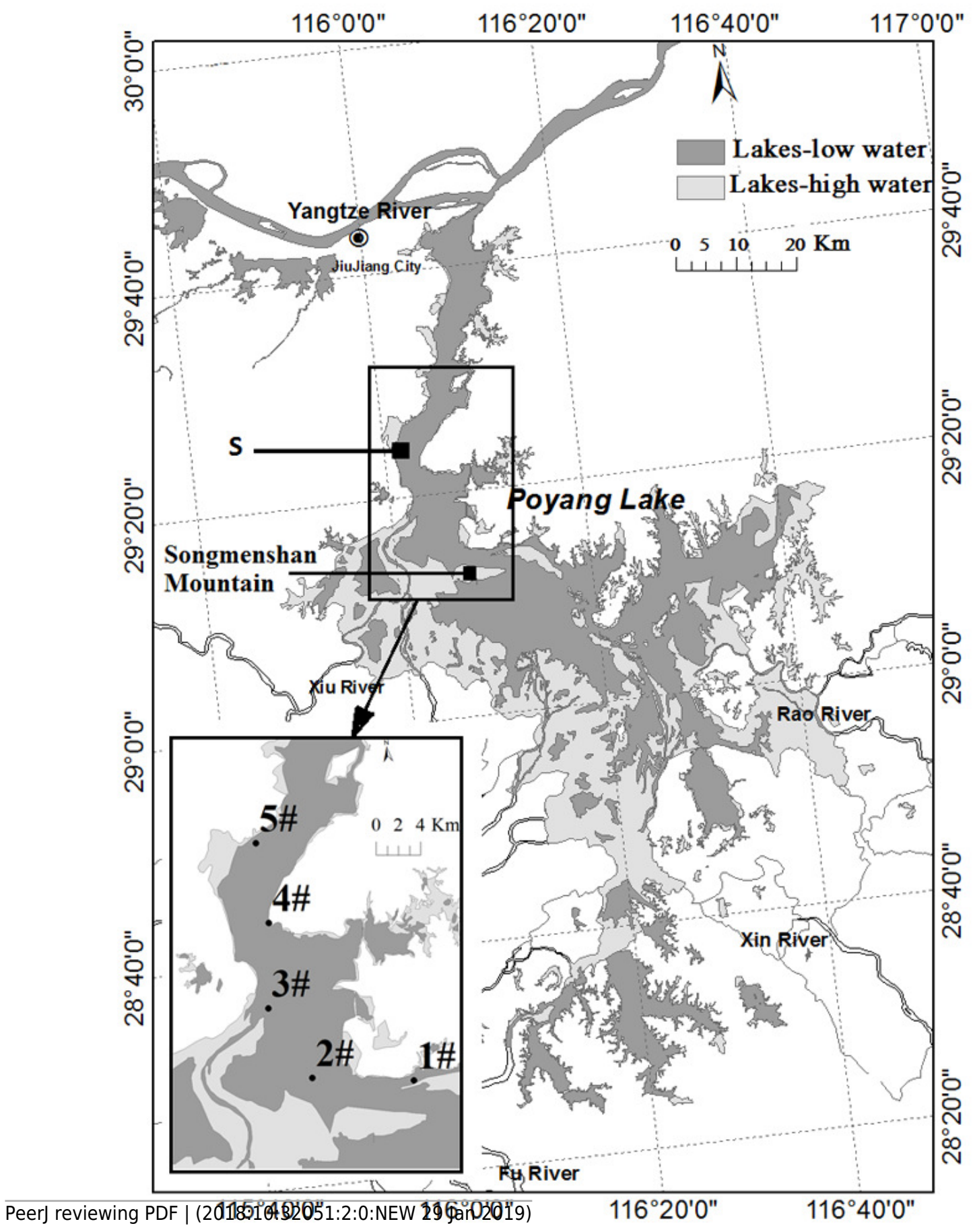


Figure 2

Water level fluctuations of Poyang Lake in the years 2013 and 2014

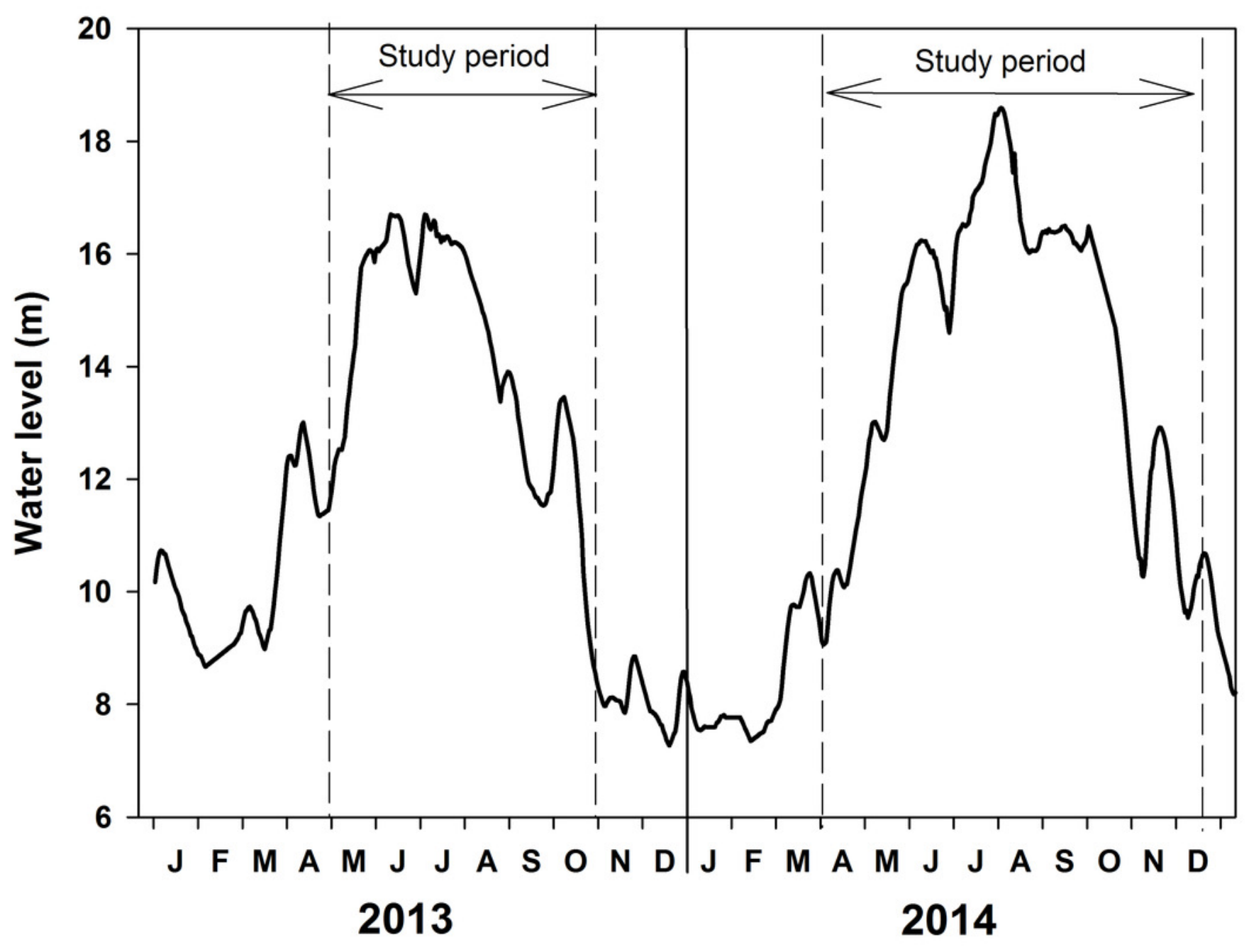




\section{Figure 3}

Variations of the measured environmental parameters in the years 2013 and 2014

(A) water temperature and water level, (B) suspended solids (SS) and transparency, (C) conductivity and $\mathrm{pH},(\mathrm{D})$ total phosphorus (TP-P) and phosphate $\left(\mathrm{PO}_{4}-\mathrm{P}\right),(\mathrm{E})$ total nitrogen (TN-N), nitrite $\left(\mathrm{NO}_{2}-\mathrm{N}\right)$, nitrate $\left(\mathrm{NO}_{3}-\mathrm{N}\right)$ and ammonium $\left(\mathrm{NH}_{4}-\mathrm{N}\right)$ and $(\mathrm{F})$ DIN and DIN/DIP 


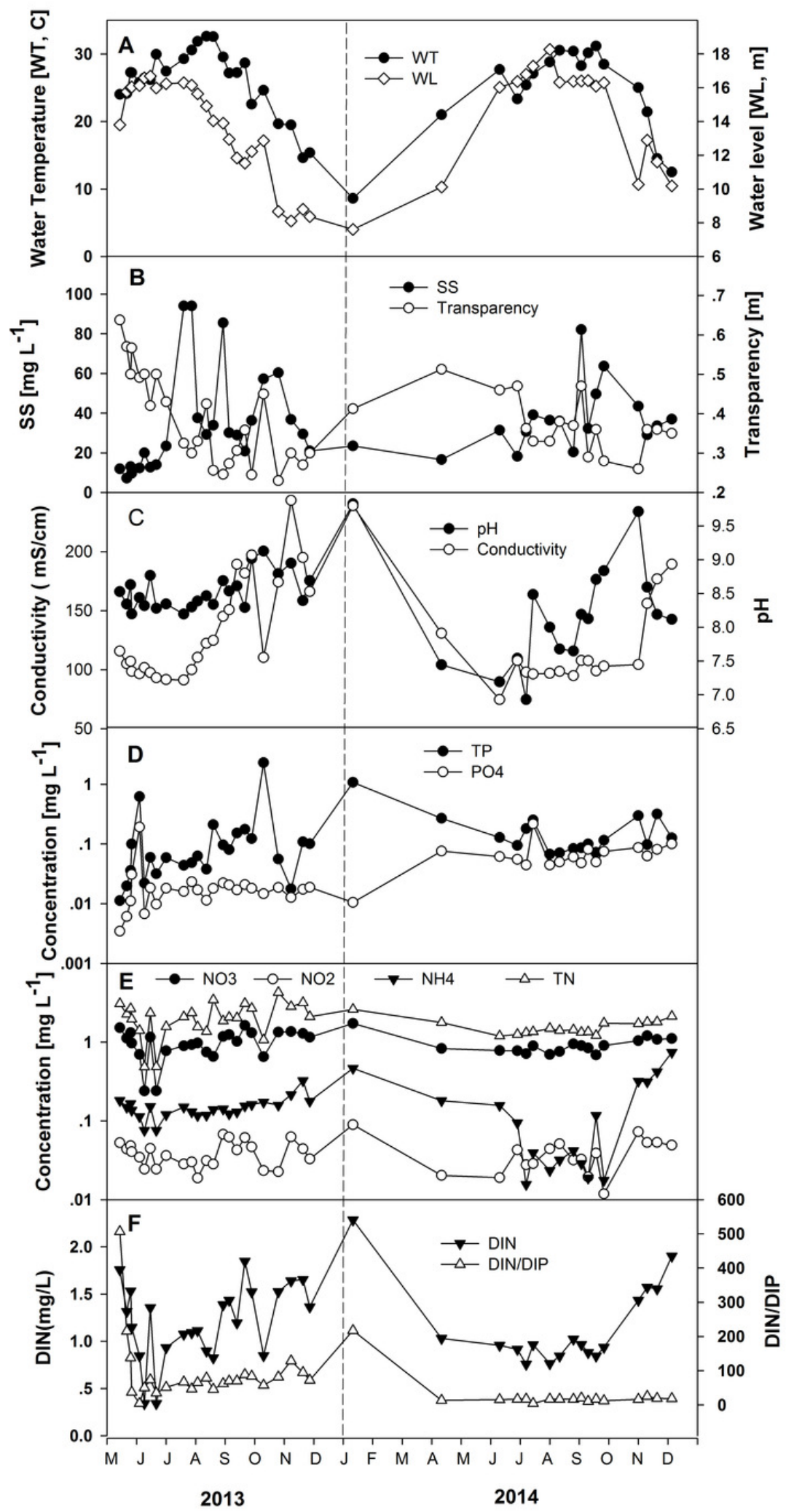




\section{Figure 4}

Variations of the phytoplankton biomass and chorophyll-a in the years 2013 and 2014

(A) Phytoplankton biomass and chorophyll-a. (B) Percent of Cyanobacteria in the total

phytoplankton biomass. (C) The relative biomass of the dominant Cyanobacteria genera. For references, the water level changes from Figure 2 is inserted as a grey line in panel B. 


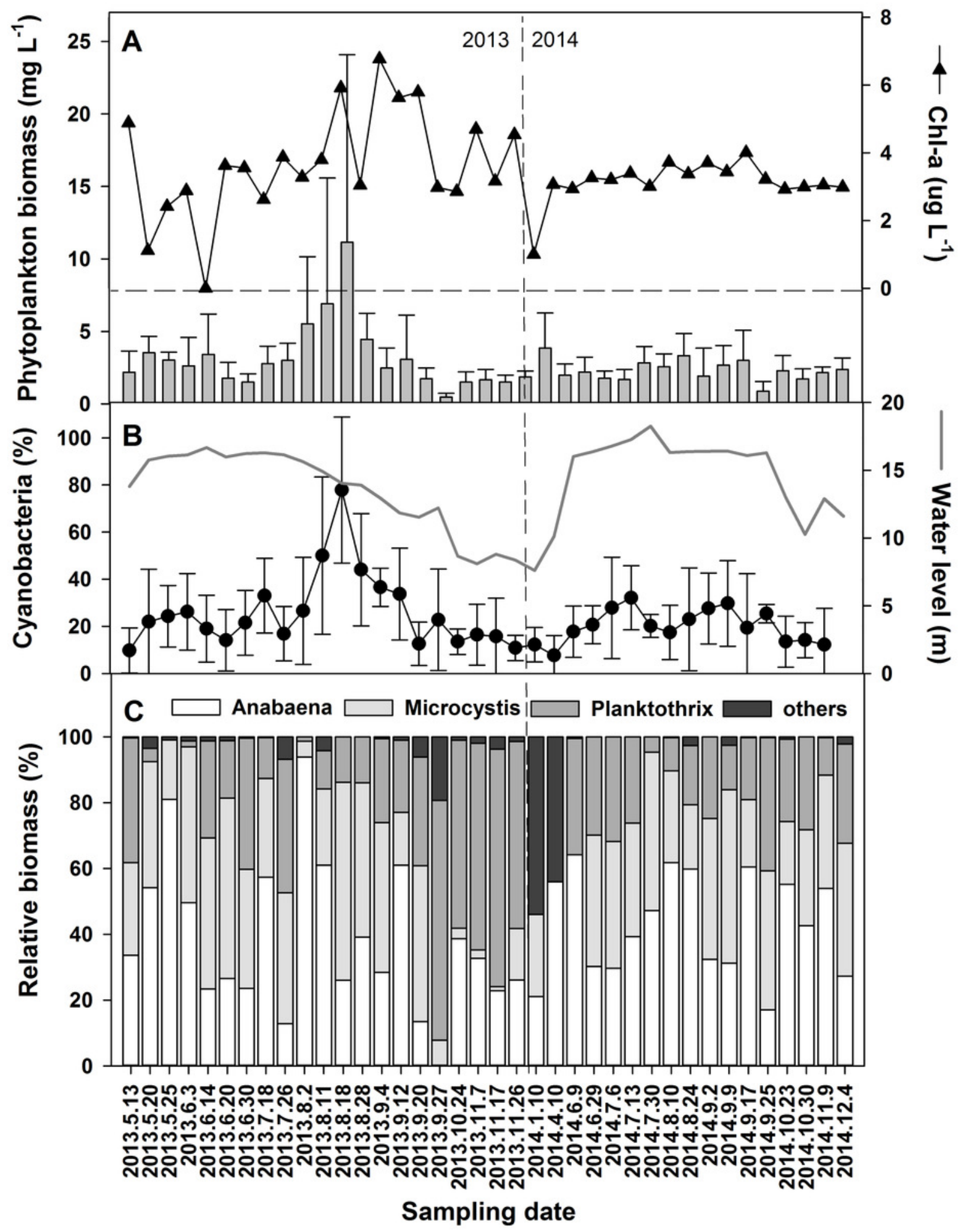


Figure 5

Variations of Anabaena abundance and Anabaena heterocyst frequency in the years 2013 and 2014

(A) Anabaena abundance. (B) Mean filament length and heterocyst frequency.

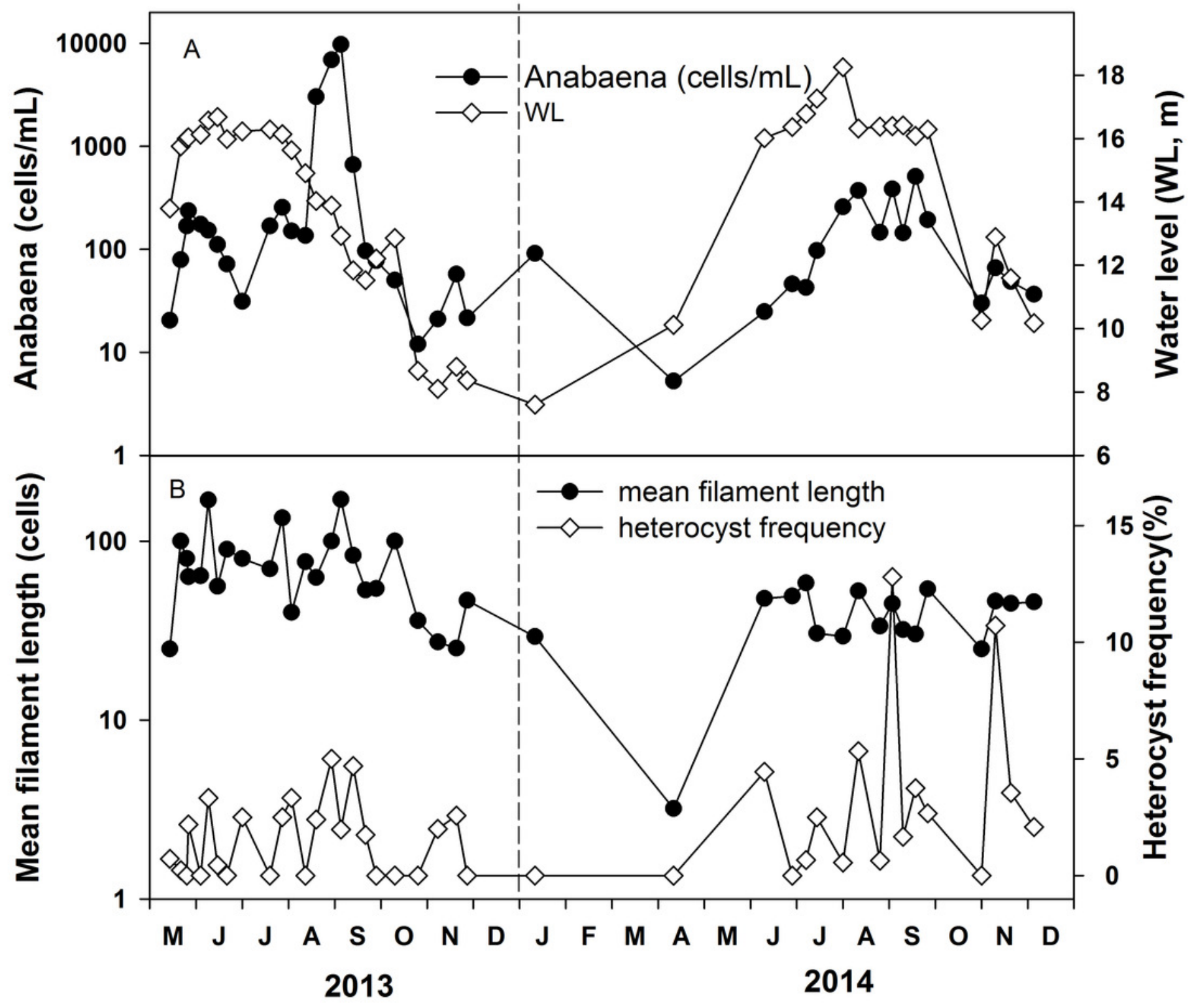




\section{Table 1 (on next page)}

Summary of statistical data for the measured variables 
1

\begin{tabular}{ccccc}
\hline & Mean & Max & Min & Std Dev \\
\hline WL $(\mathrm{m})$ & 13.79 & 18.26 & 7.6 & 3.10 \\
WT $\left({ }^{\circ} \mathrm{C}\right)$ & 25.51 & 33.31 & 10.03 & 5.41 \\
Transparency $(\mathrm{m})$ & 0.37 & 1.0 & 0.1 & 0.17 \\
$\mathrm{SS}\left(\mathrm{mg} \mathrm{L}^{-1}\right)$ & 35.90 & 203.3 & 1.4 & 33.71 \\
Turbidity $(\mathrm{NTU})$ & 45.22 & 418 & 2.4 & 37.84 \\
$\mathrm{pH}$ & 8.38 & 10.38 & 6.72 & 0.56 \\
Conductivity $\left(\mathrm{ms} \mathrm{cm}^{-1}\right)$ & 130.1 & 495.7 & 37.9 & 49.7 \\
$\mathrm{TN}\left(\mathrm{mg} \mathrm{L}^{-1}\right)$ & 1.984 & 7.3 & 0.04 & 1.07 \\
$\mathrm{NO}_{3}-\mathrm{N}\left(\mathrm{mg} \mathrm{L}^{-1}\right)$ & 0.99 & 2.17 & 0.07 & 0.34 \\
$\mathrm{NO}_{2}-\mathrm{N}\left(\mathrm{mg} \mathrm{L}^{-1}\right)$ & 0.039 & 0.18 & 0.0001 & 0.026 \\
$\mathrm{NH}_{4}-\mathrm{N}\left(\mathrm{mg} \mathrm{L}^{-1}\right)$ & 0.157 & 1.33 & 0.001 & 0.157 \\
$\mathrm{TP}\left(\mathrm{mg} \mathrm{L}^{-1}\right)$ & 0.12 & 3.63 & 0.01 & 0.29 \\
$\mathrm{PO}_{4}-\mathrm{P}\left(\mathrm{mg} \mathrm{L}^{-1}\right)$ & 0.05 & 0.85 & 0.001 & 0.067 \\
$\mathrm{DIN} / \mathrm{DIP}^{-1}$ & 43.56 & 172.43 & 0.8 & 38.16 \\
\hline
\end{tabular}

2 
Table 2 (on next page)

Correlation coefficients (Spearman's rho) between environmental variables and parameters of Anabaena 


\begin{tabular}{|c|c|c|c|c|c|c|}
\hline & herocyst & Anabaena & Cyanobacteria & phytoplankton & Chla & WL \\
\hline WL & $0.327^{* *}$ & $0.171^{*}$ & $0.215^{\text {** }}$ & 0.132 & $0.172^{*}$ & 1.000 \\
\hline WT & $0.167^{*}$ & $0.315^{* *}$ & $0.384^{* *}$ & $0.292^{* *}$ & $0.409^{* *}$ & $0.539^{* *}$ \\
\hline transparency & -0.016 & 0.012 & -0.063 & $0.219^{* *}$ & -0.106 & $0.181^{*}$ \\
\hline SS & -0.019 & 0.005 & 0.021 & $-0.259^{* * *}$ & 0.048 & -0.068 \\
\hline Turbidity & -0.049 & -0.111 & -0.099 & $-0.245^{* *}$ & -0.070 & $-0.310^{* *}$ \\
\hline $\mathrm{pH}$ & -0.063 & 0.034 & 0.054 & -0.043 & -0.001 & $-0.297^{* *}$ \\
\hline Conductivity & $-0.187^{*}$ & $-0.193^{*}$ & -0.137 & -0.145 & $-0.174^{*}$ & $-0.658^{* * *}$ \\
\hline $\mathrm{TN}$ & $-0.157^{*}$ & $-0.160^{*}$ & $-0.174^{*}$ & $-0.150^{*}$ & -0.118 & $-0.507^{* * *}$ \\
\hline $\mathrm{NH}_{4}-\mathrm{N}$ & -0.055 & -0.049 & -0.106 & 0.017 & $-0.220^{* * *}$ & $-0.561^{\text {** }}$ \\
\hline $\mathrm{NO}_{3}-\mathrm{N}$ & $-0.188^{*}$ & -0.132 & -0.128 & -0.120 & $-0.175^{*}$ & $-0.476^{* *}$ \\
\hline $\mathrm{TP}$ & 0.099 & -0.111 & -0.065 & $-0.151^{*}$ & -0.055 & 0.072 \\
\hline $\mathrm{PO}_{4}-\mathrm{P}$ & $0.247^{* *}$ & -0.057 & -0.148 & -0.042 & $-0.164^{*}$ & $0.440^{* *}$ \\
\hline DIN/DIP & $-0.255^{* *}$ & 0.020 & 0.093 & 0.023 & 0.043 & $-0.642^{* *}$ \\
\hline
\end{tabular}

**. Correlation is significant at the 0.01 level (2-tailed).

*. Correlation is significant at the 0.05 level (2-tailed). 